\title{
A new species of Sinningia Nees (Gesneriaceae) from Espírito Santo and Rio de Janeiro states, Brazil
}

\author{
Alain Chautems, Mauro Peixoto \& Josiene Rossini
}

\begin{abstract}
CHAUTEMS, A., M. PEIXOTO \& J. ROSSINI (2015). A new species of Sinningia Nees (Gesneriaceae) from Espírito Santo and Rio de Janeiro states, Brazil. Candollea 70: 231-235. In English, English abstract. DOI: http://dx.doi.org/10.15553/c2015v702a8

A new species of Sinningia Nees (Gesneriaceae) occurring in Rio de Janeiro and southern Espírito Santo is described and illustrated. It is morphologically related to Sinningia aghensis Chautems, through its large purple funnel-shaped corollas, but differs by the presence of 4-6 leaf pairs with much longer internodes, tomentose indument on stem and abaxial face of leaf blades, leaf blades wide ovate, peduncle pubescent and larger corolla. Geographic ranges of the two species do not overlap. Comments on phylogenetic relationships within subtribe Ligeriinae, a distribution map and a preliminary conservation assessment following IUCN Red List are also provided.
\end{abstract}

\section{Keywords}

GESNERIACEAE - Sinningia - Brazilian Atlantic forest - Espírito Santo - Rio de Janeiro - New species - Taxonomy

\footnotetext{
Addresses of the authors:

MP: Jardim Botanico Plantarum , Av. Brasil 2000, 13460-000 Nova Odessa, São Paulo, Brazil.

JR: Museu de Biologia Prof. Mello Leitão, Rua José Ruschi 4, 29650-000 Santa Teresa, Espírito Santo, Brazil.

Submitted on July 30, 2015. Accepted on August 24, 2015.
}

AC: Conservatoire et Jardin botaniques de la Ville de Genève, C.P. 60, 1292 Chambésy, Switzerland. E-mail: alain.chautems@ville-ge.ch

Edited by M.W. Callmander 


\section{Introduction}

Following previous accounts on g. Sinningia Nees, such as Chautems et al. (1991, 2000, 2010), Ferreira et al. (2014) and in the course of preparing a treatment of the tribe Ligeriinae for "Flora Neotropica", a new taxon first recognized in 1997 is now published. It was initially thought to be restricted to a single locality in Rio de Janeiro, but several other occurrences have been registered in recent years, extending its distribution in the NE of Rio de Janeiro state and to the southernmost part of Espírito Santo state. This part of Brazil is still little explored and harbors some patches of remnant vegetation that deserve further investigation. The description is based mainly on observation of live material in the wild or in cultivation. All cited specimens have been seen by the authors. As currently circumscribed, the genus Sinningia includes 70 species in Brazil.

Sinningia bragae Chautems, M. Peixoto \& Rossini, spec. nova (Fig. 1, 2).

Typus: BraziL. Rio de Janeiro: Mun. de Campos dos Goytacazes, Distrito de Ibitioca, Fazenda Pedra Negra, Maciço do Itaoca, sopé do Morro do Itaoca (Morro do Rato), $21^{\circ} 48^{\prime} 16$ "S 41 26'42”W, 13.XII.2004, fl. \& fr., J. M. A. Braga 7704 (holo-: RB [RB00589635]!; iso-: $\mathrm{G}$ [G0044934]!).

This species differs from $S$. aghensis Chautems by the following characters: leaves 4-6 pairs not condensed at the stem apex, adaxial face of leaf blades tomentose, 2-4 long pedunculate inflorescences in the upper leaf axils, corolla $4-5.5 \mathrm{~cm}$ long.

Herb rupicolous, arising from globose tuber, $2-9 \times 3-10 \mathrm{~cm}$ in diam. Stems erect, 20-50 cm tall, hirsute with trichomes 5-6 mm, green to vinaceous. Leaves 4-6 pairs, isophyllous, internode $1-9 \mathrm{~cm}$ long, petiole $0.3-3.5 \mathrm{~cm}$ long, vinaceous, tomentose, blades $7-15 \times$ $5-14 \mathrm{~cm}$ (uppermost pair much smaller), widely ovate, adaxial face dark green, pubescent, abaxial face light green to vinaceous, tomentose, apex obtuse, base obtuse, margin crenate-denticulate, 4-9 pairs of veins. Inflorescence ascending peduncles $10-25 \mathrm{~cm}$ long, green to reddish, pubescent, in the axils of the upper or the two upper large leaf pairs, carrying at their apex 1-5 pair-flowered cymes, main bracts $1.1-1.5 \times 0.5 \mathrm{~cm}$, green to vinaceous. Flowers nodding, pedicels $1.5-3.5 \mathrm{~cm}$ long, reddish, pubescent, calyx campanulate, sepals fused at base for $2 \mathrm{~mm}$, green with reddish apex, 7-11 × 3-6 mm, villose on external face, glabrous on inner face, triangular to lanceolate. Corolla slightly oblique, 4-5.5 cm long, tubular funnel-shaped, puberulous, throat glabrous, with yellow stripes at bottom, outside purple, cream-white at the very base and forming a nectary chamber, 6-8 $\mathrm{mm}$ in diam., then briefly constricted to 4-5 $\mathrm{mm}$ in diam., widening to $18-22 \mathrm{~mm}$ horizontally at the base of the lobes, with two longitudinal grooves dorsally, lobes subequal, spreading, 8-12 × 15-22 mm, purple. Stamens 4 , included, filaments $16-20 \mathrm{~mm}$ long, puberulous, anthers
$2 \times 2 \mathrm{~mm}$, coherent, star-shaped, pollen white; nectary composed of 2 dorsal glands, fused at base, $4 \times 2 \mathrm{~mm}$ and 3 smaller glands in lateral and ventral position, $1 \times 1 \mathrm{~mm}$. Ovary 5-7 mm long, white, pubescent, style $1.8-2.4 \mathrm{~cm}$ long, white, puberulous. Fruit $1-1.5 \mathrm{~cm}$ long, vinaceous when immature, pubescent.

Etymology. - The specific epithet honors Dr. João Marcelo de Alvarenga Braga, an active plant collector and taxonomist working at the Rio de Janeiro Botanical Garden. He is gratefully acknowledged here for sharing the discovery of this species.

Distribution and ecology. - Sinningia bragae was registered so far in the NE part of Rio de Janeiro, in the Municipalities of Campos dos Goytacazes, and Italva, as well as in the $\mathrm{S}$ of Espírito Santo in the Municipality of Alegre (Fig. 3). Other wild populations were observed by our friend Idimá G. Costa in Rio de Janeiro in the Municipalities of Cardoso Moreira, Itaperuna, and São Fidelis, but no herbarium collections were prepared. The species grows in small populations on granitic outcrops in sunny or semi-shaded situations.

Phenology. - The species flowers between October and December and produces fruits maturing around December-January.

Conservation status. - The type locality where the species was first collected around "Morro do Itacoa" is seriously threatened as the granitic outcrop was destroyed by rock blasting for the extraction of rocks and marble. This area is also subject to fires (J. M. Braga, pers. comm.). Fortunately several scattered populations of $S$. bragae were also observed further north (Fig. 3). The Extent of Occurrence (EOO) was estimated at $7,000 \mathrm{~km}^{2}$ and the new species should be assessed as "Vulnerable" [VU B1ab(iii)] following IUCN Categories and Criteria (IUCN, 2012).

Notes. - The new species is morphologically related to $S$. aghensis Chautems, through its large purple funnel-shaped corollas, but differs by the 4-6 leaf pairs with 1-9 cm internodes (vs. 2 leaf-pairs with $0.2-0.5 \mathrm{~cm}$ internodes in $S$. aghensis), tomentose indument on stem and abaxial face of leaf blades (vs. pubescent indument), leaf blades wide ovate (vs. obovate), peduncle pubescent (vs. glabrescent), corolla $4-5.5 \mathrm{~cm}$ (vs. 2.5-4.5 cm), bottom of throat yellowish nearly undotted (vs. cream with many vinaceous dots). An accession of this species was added to the molecular data produced by Perret et al. (2003, 2007), and subsequent analysis indicated that it is closely related to $S$. aghensis. Geographic distribution of S. bragae and S. aghensis do not overlap (note that the distribution of the latter extends further north in Espírito Santo (ES) and into Minas Gerais (MG) in relation to the information available at the time of its description in 1991 (Fig. 3). 

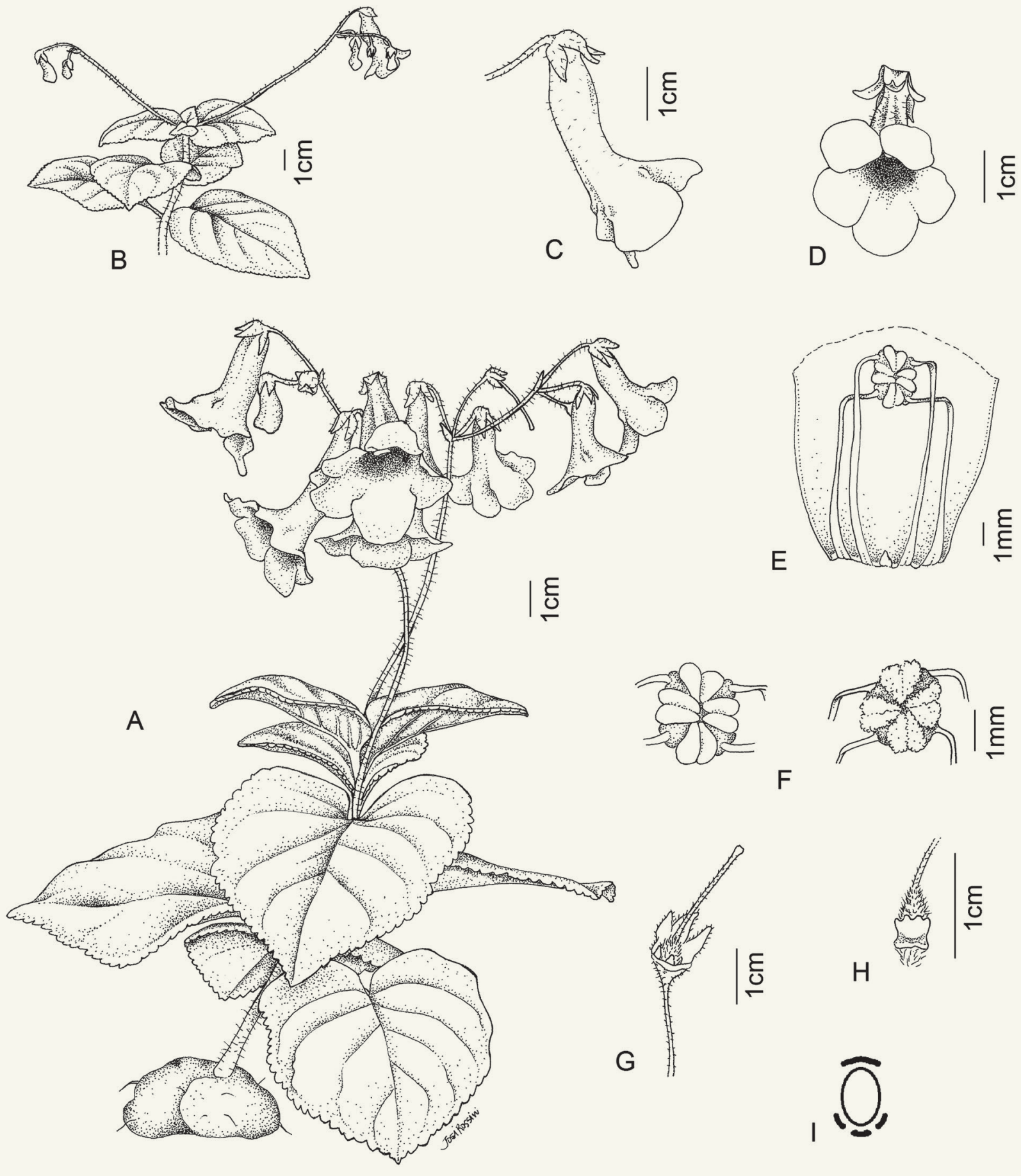

Fig. 1. - Sinningia bragae Chautems, M. Peixoto \& Rossini. A. Habit; B. Detail of the insertion of the peduncles; C. Flower (side view); D. Flower (front view); E. Insertion of stamens in the corolla; F. Anthers on the dorsal and ventral surface; G. Ovary and ventral nectary glands with corolla and two ventral lobes of the sepals removed; H. Dorsal gland nectary; I. Cross-section of the nectary glands. [Couto 963, MBML] [Drawn by Josiene Rossini] 


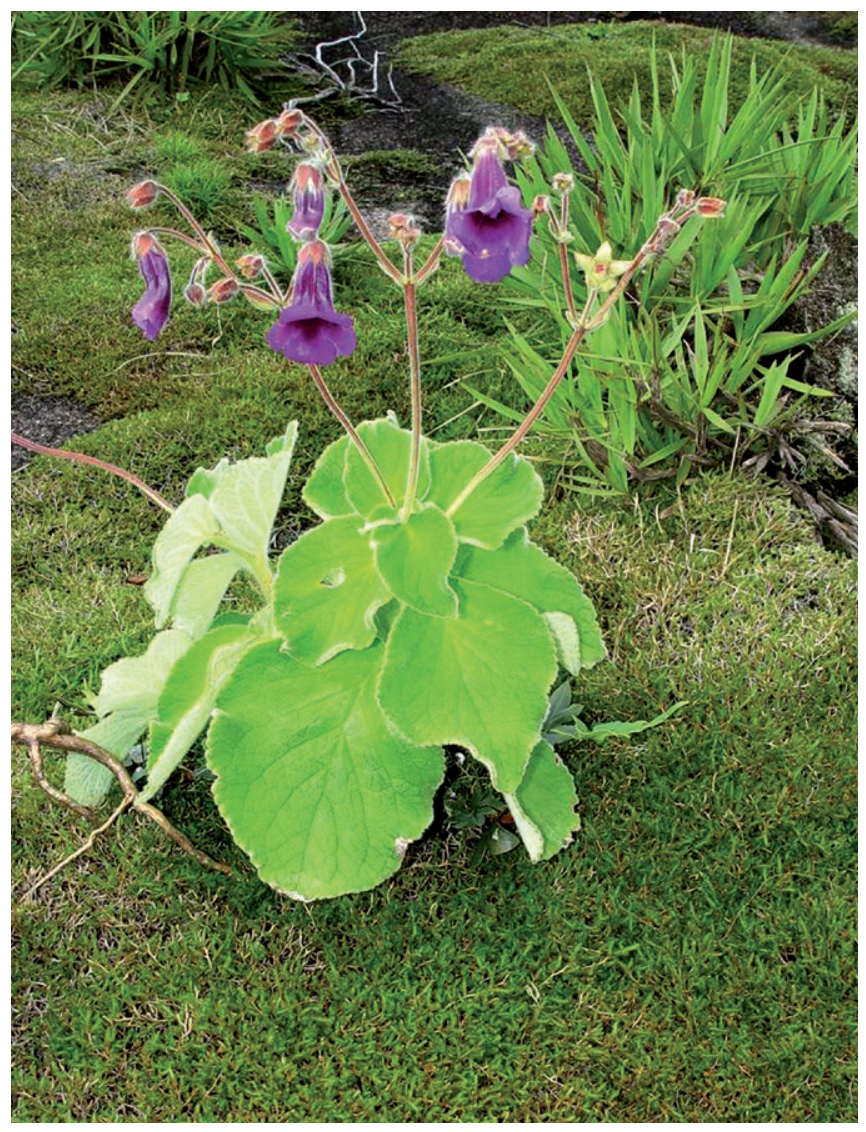

Fig. 2. - Living plant in situ of Sinningia bragae Chautems, M. Peixoto \& Rossini. [Photo: J. M. A. Braga]

Paratypi. - Brazil. Espírito Santo: Alegre, Pedra de Bons Ares, 25.X.2008, fl., D. R. Couto 1025 (MBML); Base da via Adrena Rocha, Serra da Roseira, 3.X.2008, fl., Couto 963 (MBML); Alegre, Pedra de Bons Ares, 25.X.2008, Couto 1025 (MBML); Celina, Complexo rupestre de granito, margem da BRCelina - Ibititima, comunidade de Sumidouro, ca. $600 \mathrm{~m}$ alt., Couto 1710 (VIES); Muniz Freire, PCH Santa Fé, 30.X.2006, J. M. L. Gomes 2988 (VIES). Rio de Janeiro: Campos dos Goytacazes, Distr. Ibitioca,

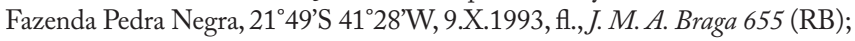
ibid. loc., 9.X.1993, fl., Braga 656 (RB); Maciço do Itaoca, Morro do Macaco, 20-200 m, 18.X.2008, M. L. Dan \& J. M. Aguiar Ita 38 (G); Distr. Morro do

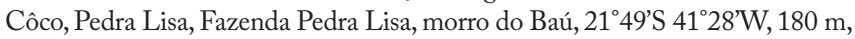
10.XI.2004, Braga 7646 (G, RB); Italva, Pão de Ló, 300 m, 2.I.2010, fl., Costa 5 (GFJP); Duas Barras, Pedra do Elefante, X.2011, fl., Costa 170 (GFJP); Campos dos Goytacazes, Serra da Bela Joana, em afloramento à margem esquerda do rio Bela Joana, 6.X.2012, fl., Costa 189 (RB).
Material in cultivation. - Material of this species was distributed among members of the Gesneriad Society in the last ten years under the name Sinningia sp. 'Ibitioca'and is currently listed in the published Gesneriad Society Seed Fund [see Gesneriads 65(3): 3-8]. A story of its discovery was published in the Gesneriad Society magazine (CHen, 2005). In the Geneva Botanical Garden scientific collection, it is kept under Accession \# AC-2808. According to a grower, a nice rose scent when sniffing the flowers can be perceived, but we were unable to detect any smell in our material kept in cultivation.

\section{Acknowledgments}

We are grateful to Idimá G. Costa who guided us in the field during several field trips in Rio de Janeiro, to Dayvid Couto for communicating the occurrences of the species in Alegre (ES), to J. M. A. Braga for making available the pictures reproduced in this paper, and to Conselho Nacional de Desenvolvimento Científico e Tecnológico (CNpQ) (Brazil) for granting the collecting permit (proc. CNPq no 000745/2012-0). We thank Gabriel E. Ferreira for preparing the species distribution map, David Zaitlin and Jim Smith for their careful revision of earlier versions of the manuscript. 


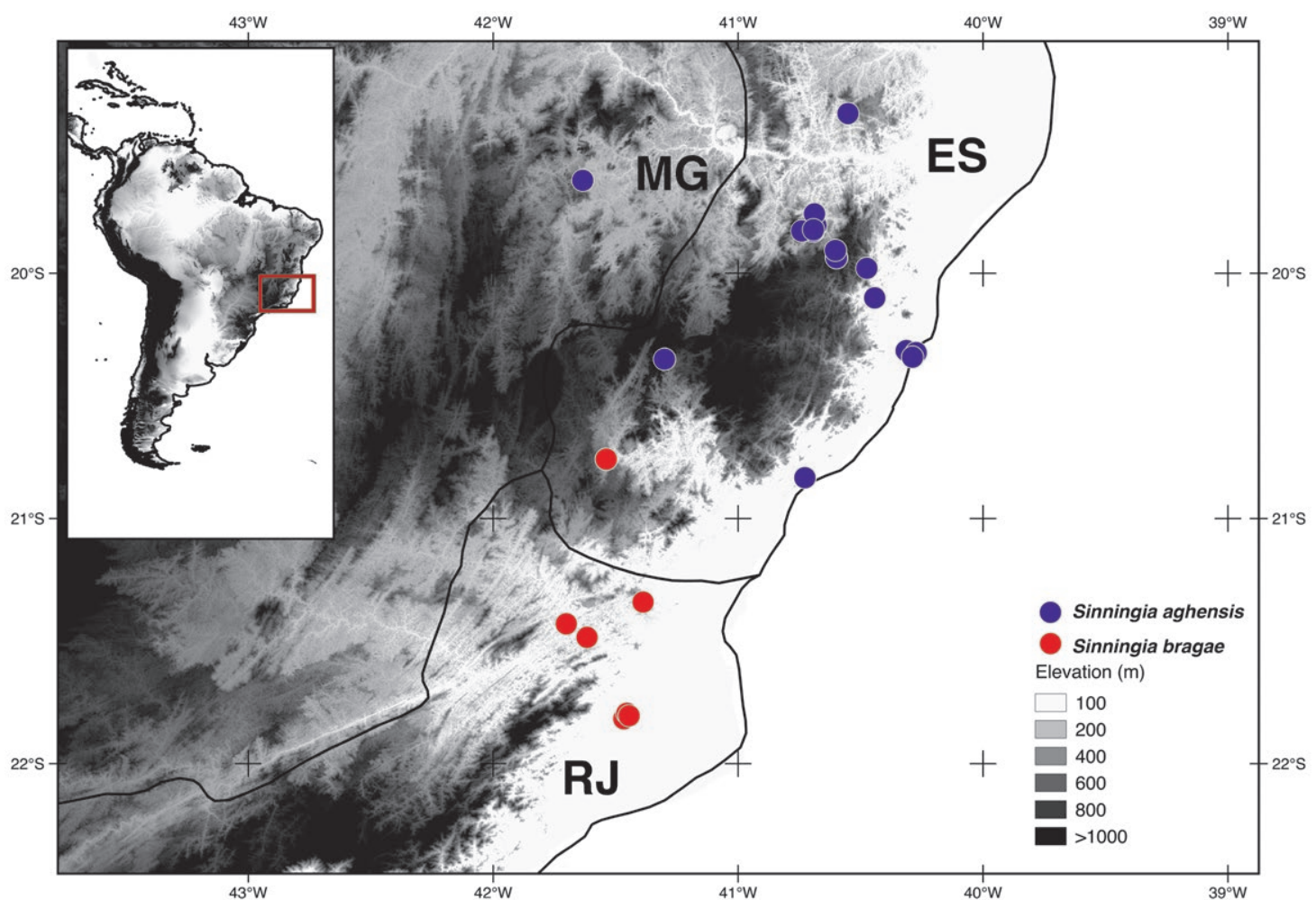

Fig. 3. - Geographic distribution of Sinningia bragae Chautems, M. Peixoto et Rossini in Rio de Janeiro (RJ) and S. aghensis Chautems.

\section{References}

Chautems, A. (1991). Taxonomic revision of Sinningia Nees II: new species from Brazil. Candollea 46: 411-425.

Chautems, A., G. S. Baracho \& J. A. Siueira filho (2000). A new species of Sinningia (Gesneriaceae) from northeastern Brazil. Brittonia 52: 49-53.

Chautems, A., T. C. C. Lopes, M. Peixoto \& J. Rossini (2010). Taxonomic revision of Sinningia Nees (Gesneriaceae) IV: six new species from Brazil and a long overlooked taxon. Candollea 65: 241-266.

Chen, T. Y. (2005). The Saga of Sinningia sp. 'Ibitioca'. Gloxinian 55: 15-17.

Ferreira, G. E.,J. L. Waechter \& A. Chautems (2014). Sinningia ramboi (Gesneriaceae) a new species from South Brazil. Syst. Bot. 39: 975-979.
IUCN (2012). IUCN Red List Categories and Criteria Version 3.1. $2^{\text {nd }}$ ed. IUCN Species Survival Commission, Gland \& Cambridge.

Perret, M., A. Chautems, R. Spichiger, T. G. Barraclough \& V. Savolainen (2007). The geographical pattern of speciation and floral diversification in the neotropics: The tribe Sinningieae (Gesneriaceae) as a case study. Evolution 61: 1641-1660.

Perret, M., A. Chautems, R. Spichiger, G. Kite \& V. Savolainen (2003). Systematics and evolution of tribe Sinningieae (Gesneriaceae): Evidence from phylogenetic analyses of six plastid DNA regions and nuclear ncpGS. Amer. J. Bot. 90: 445-460. 